\title{
Robustless Test Of Several Potato Clon In The Medium Plains
}

\author{
Syahbudin Hasibuan ${ }^{1}$, Ahmad Rafiqi Tantawi ${ }^{2}$, Gusmeizal ${ }^{3}$ \\ Staff Lecture Agriculture Faculty University Medan Area Kolam Street No 1. Medan Estate North Sumatera \\ Indonesia \\ Corresponding Author: Syahbudin Hasibuan
}

\begin{abstract}
Expansion Of Potato Plant In Medium Plain Has Geographical Obstacles Concerning With Its Characteristics Of Which Requires A Relatively Low Temperature During Growth Stage, Especially At Tuber Formation Which Requires The Optimum Temperature Of 180 Oc. Escalating Temperatures Imply A Greater Rate Of Gibberellin Synthesis In Leave Bud And Stolon Tip, And Indicating A Modification Of Stolon Into Tuber Is Impaired. Apart From That, Planting Of The Potato In Medium Plain Requires Adaptive Variety Which Can Tolerate High Temperature And Drought Stress. The Main Of Objective Research Was To Find Out Potato Variety Which Was Relatively More Adaptive To High Temperature In The Medium Plains. This Research Was Conducted In Sibolangit District (680 Asl), Deli Serdang Regency, North Sumatera, Started From April Until July 2016. Treatments Consisted Of 7 Potato Varieties Which Were Arranged In A Simple Randomized Block Design And Replicated Three Times. Results Showed That Plant Height Was Significantly Different Among Varieties Evaluated, Whereas Greenness Intensity Of Leaves Seemed Homogeneous Among Varieties. Several Morphological Characters Of The Potato Including Leaf Area Index (LAI), Leaf Canopy Structure, Leaf Arrangement, Growth Habit, Stem Anthocyanin, A Frequency Of Flowering, And Color Of Flower Crown Are Significantly Varied Depend On Crop Genotypes.
\end{abstract}

Keywords: Potato, Medium Plains, Variety, Morphological Characters, Temperature

Date of Submission: 25-07-2017

Date of acceptance: 10-08-2017

\section{Introduction}

Potato (Solanum tuberosum L.) is one of alternative commodity in supporting food endurance. Sweet potato has a more superiority in producing carbohydrate nutrition rather than other commodities such as rice. Potato contains lower carbohydrates and fats, while the satiety index, sugar content (glycemic index), vitamin $\mathrm{B} 1$ composition, vitamin $\mathrm{C}$, fiber and mineral content are higher than rice. In every $100 \mathrm{~g}$ of potatoes contain 83 $\mathrm{kcal}, 19 \mathrm{~g}$ carbohydrate, $2 \mathrm{~g}$ protein, $0.1 \mathrm{~g}$ fat, $2.2 \mathrm{~g}$ fiber, $78 \mathrm{~g}$ water, $0.11 \mathrm{mg}$ of vitamin $\mathrm{B} 1,17 \mathrm{mg}$ of vitamin $\mathrm{C}, 11 \mathrm{mg}$ calcium, $56 \mathrm{Mg}$ fluorine, $0.7 \mathrm{mg}$ iron, 62 glucose levels and 328 of satiety index (Munarso and Arsanti, 2009).

In Indonesia, the consumption of potato per capita continued to increase from $0.98 \mathrm{~kg}$ per capita per year in 1980 to $1.37 \mathrm{~kg}$ per capita per year in 1999 (Funglie et al., 2003). Moreover, according to the Indonesia Economic Census (Susenas), consumption of potatoes reaches to $1.73 \mathrm{~kg}$ per capita per year, and then in 2010 increased by $6.4 \%$ to $1.84 \mathrm{~kg}$ per capita per year and predicted by the end of 2013 will reach $2.06 \mathrm{~kg}$ per capita per year (BPS, 2011). This is due to the reducement of rice consumption by $1.4 \%$ from 2009 to 2011 , as well as the population growth, consumption patterns alteration, and the expansion in potato industry that processes into potato chips, French fries, and potato flour.

Unfortunately, the increasement of the consumption is not in line with the production. Thus, several means supposed to be conducted in complishing a sufficient production. Those means are divided into two categories, namely intensification and extensification effort. Intensification effort has been conducted including the utilization of superior varieties even the improvement of cultivation techniques, also the extensification effort including geographical constraints related to the characteristics of plants which are need the low temperatures during their growth.

Places with high elevation, such as medium plains usually related to temperature differences, especially day and night temperatures. Generally, the medium plains exceed the optimal temperature which is requirment for the potatoes to grow and produce properly. Ashandhi and Gunadi (2006) explained that areas with a maximum air temperature of $30^{\circ} \mathrm{C}$ and a minimum air temperature of $15{ }^{\circ} \mathrm{C}$ are suitable for potato to growth rather than areas with constant temperatures relatively at $24{ }^{\circ} \mathrm{C}$. A good development in potatoes formatting occurs in sub-tropical climates and in the tropical highlands with the day-time temperatures at $25{ }^{\circ} \mathrm{C}$ and the evening air temperature at $17^{\circ} \mathrm{C}$ or lower. According to Burton (1981), the increasement of temperature causes the improvement of growth rate and photosynthesis rate until it reaches the maximum, then it decreases. At the same time, respiration rate gradually increases with escalating temperature. For the increasement temperature as 
much as $10{ }^{\circ} \mathrm{C}$, the respiration will be doubled. Consequently, the loss of photosynthesis through the respiration is substantial rather than the addition, which is generated by photosynthetic activity. Hence, the net value of dry weight potato was decreased. Besides, soil temperature also determines the tuberization. Yamaguchi (1991); Smith and Rappaport (1977) reported that an optimum potato formation requires $24^{\circ} \mathrm{C}$ of soil temperature during the day and $14.9^{\circ} \mathrm{C}$ to $17.7^{\circ} \mathrm{C}$ at night.

The decreasement of elevation is causing an increased temperature, which is able to affecting a tension in high temperatures. For the soil temperatures at $30 \mathrm{oC}$, the activities of some enzymes in starch metabolism were disturbed causing in decreasement of starch levels in potatoes (Mares et al., 1985; Syahbudin, 2013). Thus, the accumulation of plant dry materials are reducing caused by the total carbohydrates which are produced from photosynthesis, is smaller than that used for respiration (Asandhi and Gunadi, 1989). In addition, Wattimena et al. (1991) stated that a high difference of temperature between day-time and evening is an inhibator factor of potato formatting. Therefore, a study is needed in determining the area along the medium plateau.

The main issue regarding the cultivation of potatoes in the medium plains is the high temperature (Ewing and Struik, 1992). At the high temperatures, transformation of stolon into yams will be inhibited (Stark and Love, 2003), and an increasement of gibberellin hormone synthesis in the leaf buds (Vreugdenhil and Sergeeva, 1999), and at stolon tip (Struik et al., 1999). Giberelin has been proven to inhibit the formation of yams (Tekalign and Hammes, 2005).

Other than that, varieties are considered as the critical determinants of successful potato cultivation in the medium plains. Along with its requirement of low temperature during their growth, the relative varieties were needed to be more adaptive with higher temperatures in the medium plains.

\section{Materials Dan Method}

The field study aims to discover the characteristic appearance of growth and result from several varieties of potato, and then to identify the adaptability of those varieties in the medium plains. The research was conducted at Sibolangit (680 m dpl), Deli Serdang District, and North Sumatra, Indonesia from March to August 2015. The study used a total of 7 superior varieties, gathered from Indonesian Vegetables Research Institute of Lembang, Bandung namely: Atlantic, Margahayu, Amabile, Median, Kastanum, Maglia and Granola. The experiments were arranged in a simple randomized block design and repeated three times. The treatment factor is potato variety (V) consist of 7 levels. There are 21 units of experimental plots, each plot measuring $3 \mathrm{mX} 1.2 \mathrm{~m}$, with spacing in a 30 $\mathrm{cm}$ row and between $60 \mathrm{~cm}$ rows. Then, The cattle manure (30 t/ha) as the basic fertilizer is given 1 week before covered with the black-silver plastic mulch, planted in two rows in order to fit as many 20 plants for one plot. As the inorganic fertilizer, the pearl fertilizer (15:15:15) is given with a dose of $125 \mathrm{~kg}$ per ha- 1 in 2 stages, which are 2/3 during the planting time and 1/3 given 1 month after the planting along with weeding the weed. Then again, the study used the Curacron 500 EC insecticide, Antracol 250 EC, Decis 250 EC, Confidor 250 EC and Dithane M45 fungicide for the pest and disease control with consideration of type and dose adjusted with symptoms in the field. Finally, harvesting is organized after the leaves begin to dry or at age of 75 days after planting.

The research also observed the morpological character parameters, namely plant height, leaf size (length and width of the leaf), stem thickness, leaf canopy structure, growing habit, anthocyanin stem staining, flower frequency, flower crown color. The observation was performed on leaves of the upper third on the main stem. All characters were observed during the flowering plants $(\mathrm{N}=35)$ and conducted by using Individual Testing Guide (PPI) of potato BUSS (Pusat Perlindungan Varietas Tanaman, 2006).

\section{Results And Discussion}

The morphological observation (quantitative characters) shows that varieties significantly effecting on plant height, while the main stem thickness and leaf size have no effect on the tested 7 varieties. See Table 1.

Table 1. Variance analysis results of quantitative characters (plant height, main stem thickness, leaf size and 7 potato varieties.

\begin{tabular}{|l|c|c|}
\hline \multicolumn{1}{|c|}{ Quantitative Characters } & Clone & KK (\%) \\
\hline Plant Height & $* *$ & 18,5 \\
\hline Main Stem Thickness & NS & 15,7 \\
\hline Leaf Length & NS & 10,3 \\
\hline Leaf Width & NS & 8,9 \\
\hline
\end{tabular}

Notes : $\quad * *=$ Has a significant effect on the level of $1 \%$

NS $=$ Has no significant effect on the $5 \%$ level.

As listed in Table 2, the varieties of Atlantic, Margahayu and Amabile were more vigorous than varieties of Median, Kastanum, Maglia and Granola. Marpugo and Ortiz (1988) and Amadi et al. (2008) explained that the difference between clon tolerant and vulnerable of hot temperaturess can be determine by the plant height, number of segments and total leaves. Subsequently, a study by Hamdani and Simarmata (2005) pointed out that for the soil 
temperatures above than $22^{\circ} \mathrm{C}$ will be increasing the stem extension and raise the number of stem segments. This is due to the increasement of gibberellic acid content in plants due to high temperatures.

Table 2. The averages of plant height, main stem thickness, leaf length and width of 7 varieties of potato.

\begin{tabular}{|l|c|c|c|c|}
\hline \multicolumn{1}{|c|}{ Variety } & $\begin{array}{c}\text { Plant Height } \\
(\mathrm{cm})\end{array}$ & $\begin{array}{c}\text { Main Stem } \\
\text { Thickness }(\mathrm{mm})\end{array}$ & Leaf Length $(\mathrm{cm})$ & Leaf Width (cm) \\
\hline Atlantic & $57,3 \mathrm{a}$ & 7,4 & 13,2 & 9,2 \\
\hline Margahayu & $43,6 \mathrm{ab}$ & 7,3 & 12,9 & 9,3 \\
\hline Amabile & $45.9 \mathrm{ab}$ & 7,6 & 12,7 & 9,0 \\
\hline Median & $35,5 \mathrm{ab}$ & 5,5 & 14,9 & 9,9 \\
\hline Kastanum & $33.4 \mathrm{~b}$ & 6,2 & 14,7 & 9,7 \\
\hline Maglia & $32.7 \mathrm{~b}$ & 6.1 & 14,5 & 10,1 \\
\hline Granola & $34.2 \mathrm{~b}$ & 5,9 & 14,2 & 9,8 \\
\hline
\end{tabular}

Notes: Numbers in the same column followed by the same letter was have no significant effect on the $5 \%$ level according to the BNJ Test.

As shown in Table 2, the leaf size is one of the character that affected by the increase of temperature. A higher temperatures as in the medium plains bring the reduction of leaf size. The circumstance is a morphological adaptation mechanism by plants to minimize the transpiration rate. Fleiser et al. (1986) explained that the more elevated of optimum temperature enable to decrease the leaf area and size. This is related to the plant metabolism transformation that leads to plants tolerance with the high temperature through reduction of water-loss by lowering the surface area of transpiration. Potato has three types of the patterns of growt habit, namely upright, semi upright and spreading. Handayani, et al. (2011) stated that "spreading" is the one of growt habit that suitable for planting in mediun or low plains. This is related to ability of canopy to suppress evaporation through the ground cover so it can be reducing the soil temperature. Then, a high soil temperature is able to causing the tuberization inhibition. Meanwhile, the canopy structure allows plants to increase the efficiency of sunlight for assimilation processes. Table 3 illustrates the patterns of growt habit by the varieties. The upright type is found in 2 varieties namely Median and Granola. Then, type of spread is found in Amabile and Margahayu varieties, while other varieties such as the Atlantic, Kastanum and Maglia mentioned as the semi upright type.

Table 3. The growt habit, canopy structures of leaves, and staining anthocyanin for stem from 7 varieties

\begin{tabular}{|c|c|c|c|}
\hline Varieties & Growt Habit & Canopy Structures & Staining Anthocyanin for Stem \\
\hline Atlantic & Semi upright & Midst & Moderate \\
\hline Margahayu & Spread & Midst & Strong \\
\hline Amabile & Spread & Leaf & Moderate \\
\hline Median & Upright & Stem & Weak \\
\hline Kastanum & Semi upright & Stem & Weak \\
\hline Maglia & Semi upright & Midst & Moderate \\
\hline Granola & Upright & Midst & Moderate \\
\hline
\end{tabular}

As illustrated in Table 3, the canopy structures of leaves and staining anthocyanin for stem are influencing the variance of varieties. Amabile is the only one of varieties that has the type of leaf for its canopy structures and covered the stem. Then, canopy structures of Atlantik, Margahayu, Maglia dan Granola are stand in the middle of stem. Besides, Median and Kastanum have the canopy structures with stem type. The characteristic of stem anthocyanin staining also indicates the diversity between the varieties. As can be seen in Table 3, the varieties show the strentgh of stem anthocyanin staining, starts from strong, moderate, and weak.

Further, the study also indicates the diversity between the varieties towards the leaf and flower morphology (e.g. leaf structure, flower frequency and flower crown color). As can be seen in Table 4, the difference of green color characteristic intensity was not found on any varieties. All of the varieties have green color for the leaf with middle intensity.

The varieties of Margahayu, Amabile, and Granola have the opened leaf structure with a strong existence for their secondary leaf. This leaf structure type has the distance between the leaf strands and avoiding an overlapping for each other. Next, the varieties of Atlantic, Median, Kastanum dan Maglia have a medium type for the leaf structure. This leaf structure type have a strong existence for their secondary leaf and able to covering the ground surface. The circumstance was a morphologic adaptation by plants to minimize the evaporation and maintaining the soil temperatures to remain stable and involve the tuberization. 
Table 4. Leaf and flower morphology (e.g. leaf structure, flower frequency, and flower crown color) from 7 varieties of potato in the medium plains

\begin{tabular}{|l|l|l|l|l|}
\hline \multicolumn{1}{|c|}{ Varieies } & \multicolumn{1}{c|}{$\begin{array}{c}\text { Leaf } \\
\text { Structure }\end{array}$} & Leaf Green Color Intensity & \multicolumn{1}{c|}{$\begin{array}{c}\text { Flower } \\
\text { Frequency }\end{array}$} & Flower Crown Color \\
\hline Atlantic & Medium & Medium intensity & Medium & White \\
\hline Margahayu & Opened & Medium intensity & Less & White \\
\hline Amabile & Opened & Medium intensity & Less & White \\
\hline Median & Medium & Medium intensity & --- & --- \\
\hline Kastanum & Medium & Medium intensity & Medium & White \\
\hline Maglia & Medium & Medium intensity & --- & --- \\
\hline Granola & Opened & Medium intensity & xxx & xxx \\
\hline
\end{tabular}

Notes : --- : non-survival variety until flower morphology observation $\mathrm{xxx}$ : non-producing flower variety

To sum up, there are 5 varieties that has been observed for the flower frequency and the flower crown color, namely: Atlantic, Margahayu, Amabile, and Kastanum. Meanwhile, the variety of Median and Maglia cannot be observed due the plants were dying before conducting the research. In contrast, Granola does not produce any flower.

\section{Conclusion}

The morphology of potato in the medium plains has a high of diversity depends on its variety. The result proposes 3 adaptive varieties in the medium plains, namely: Margahayu, Amabile, and Atlantic. The recommendation was based on the morphologic characteristic such as: plant height, main stem thickness, length and width of leaf, canopy structures, growt habit, leaf structures, and its survival.

\section{Acknowledgement}

Author would like to thank to Indonesian Directorate General of Higher Education to facilitate the research through the program of Decentralization of Competitive Grant Research DIPA Kopertis I in 2015.

\section{Reference}

[1]. Amadi, C.O., E.E. Obong, J.C. Okonkwo, and A.K. Danbaba. 2008. Evaluation of some potato hybrids and their parents in a location with supra-optimal temperatures. PAT, 4(2):38-52

[2]. Asandhi, A. A., dan N. Gunadi. 2006. Syarat Tumbuh Tanaman Kentang. Dalam Buku Tahunan Hortikultura, Seri : Tanaman Sayuran. Direktorat Jenderal Tanaman Pangan dan Hortikultura. Jakarta.

[3]. Asgar, A. dan Kusdibyo, 1997. Pengaruh varietas dan umur panen terhadap kualitas umbi kentang (Solanum tuberosum) sebagai bahan baku pembuatan kripik kentang. Prosiding Seminar Nasional Teknologi Pangan. Kantor Mentri Negara Urusan Pangan Republik Indonesia.

[4]. Asmamaw, Y and Tekalign, T. 2010. Specific Gravity, Dry matter Concentration, pH, and Crisp-Making Potential of Ethiopian Potato (Solanum tuberosum L.) Cultivars as Influenced by Growing Environment and Length of Storage Under Ambient Conditions. Potato Research, 53: 95-109.

[5]. Badan Pusat Statistik. 2011. Prediksi kebutuhan kentang per kapita. Melalui http://www.bps.go.id (12/01/2012)

[6]. Balami, V and B. W. Poovaiah. 1985. Retardation of shoot growth and promotion of tuber growth of potato plants by paclobutrazol. American Potato Journal, 62:363-369.

[7]. Burton, W.G. 1981. Challenges for stress physiology in potato. Am. Potato J. 58: 3-14.

[8]. Duriat, A. S., Soetrisno, T.A. Prabaningrum, L dan R. Sutaryo. 1994. Penerapan pengendalian hama penyakit terpadu pada budidaya kentang. Balithorti Lembang.

[9]. Ewing, E. E., and P. C. Struik. 1992. Tuber formation in potato: Indduction, initiation, and growth. Hort. Rev.14:89-197.

[10]. Ewing, E.E. 1981. Heat stress and the tuberization stimulus. Am. Potato J. 58: 31-50

[11]. Fleisher, D.H., D.J. Timlim and V.R. Reddy. 2006 Temperature influence on potato leaf and branch distribution and on canopy photosynthetic rate. Agron. J. 98: 1442-1452

[12]. Hamdani, J. S., T. Simarmata. 2005. Respon Tanaman kentang (solanum tuberosum L.) kultivar Panda terhadap pupuk organic olahan dan pupuk NPK lengkap di Kamojang Majalaya. Kultivar 4(1): 41-47

[13]. Handayani. T., Eri Sofiari dan Kusmana Karasteristik Morfologi Klon Kentang di Datarn Medium. Buletin Plasma Nutfah Vol. 17 N0. $2(116-121)$

[14]. Mares, D. J., Joseph R. Sowokinos, and John S. Hawker. 1985. Carbohydrate metabolism in developing tubers. P. 280-318 In P. H. Li, (ed.) Potato Physiology. Acad. Press, New York.

[15]. Mares, D. J., and H. Marschner, 2003. Assimilation conversation in potato tuber in relation to starch deposition and cell growth. Ber. Otsh. Bot. Ges. 93:299-313.

[16]. Marpugo, R. and R. Ortiz, 1988. Morphology variation of potato (solanum spp) under contrasting environments. Environmental and ExperimentalBotani. 28(3): 165-169

[17]. Menzel, C. M. 1983. Tuberization in potato at high temperatures : Giberellin content and transport from buds. Ann. Bot. 52:697702 .

[18]. Munarso, J, dan Arsanti, I.W. 2009. Komoditas kentang sebagai pangan alternatif unggulan. Prosiding Seminar Nasional Pekan Kentang. PUSLITBANG Hortikultura. Departemen Pertanian.

[19]. Rubatzky, V, and E. Yamaguchi. 1998. Sayuran Dunia. ITB Press. Bandung. 331 p.

[20]. Sarquis, J. I., H. Gonsales, and I. Bernal-Lugo. 1996. Response of two potato clones (Solanum tuberosum) to contrasting temperature regimes in the field. Amer. Potato J. 73:285-300. 
[21]. Smith, O. E., and L. Rappaport. 1977. Giberellin inhibitors and tuber formation in the potato (Solanum tuberosum. L) Am. Potato J. 46:185-191.

[22]. Stark, J. C. and S. L. Love. 2003. Potato Production Systems: a Comprehenshive Guide for Potato Production. University of Idaho Extension. Idaho. U.S.A. 426

[23]. Struik, P. C., Dick, V., Herman J.V.E., Kristian W.B., and Richard G.F. 1999. Physiological and genetic control of tuber formation. Potato Research 42:313-331.

[24]. Syahbudin, 2013. Penigkatan kualitas hasil ubi tiga varietas kentang melalui aplikasi Paklobutrazol di Dua Dataran Medium. J Ijas 3(1), April 2013

[25]. Takalign, T., and P. S. Hammes. 2005. Growth responses of potato (Solanum tuberosum) grown in a hot tropical lowland to applied paklobutrazol: 2. Tuber attributes. J. Crop and Horticultural Science, 33:43-51.

[26]. Takalign, T., and P. S. Hammes. 2004. Respon of potato growth non-inductive condition to paklobutrazol: shoot, chlorophyll content, net photosynthesis, assimilate partitioning, tuber yield, quality, and dormancy. J.Plant Growth Regulation 43:227-236.

[27]. Wattimena, G. A., L. W. Gunawan, N. M. Massjik, E. Syamsudin, Ni Made A Wiendi A., dan Ernawati. 1991 Bioteknologi Tanaman. Pusat Antar Universitas Bioteknologi Institut Pertanian Bogor, Bogor.

[28]. Yamaguchi, M. 1991. World Vegetable. An Avi Book. Van Nostrand-Reinhold Co., California.

Syahbudin Hasibuan. "Robustless Test Of Several Potato Clon In The Medium Plains." IOSR Journal of Agriculture and Veterinary Science (IOSR-JAVS), vol. 10, no. 8, 2017, pp. 61-65. 